\title{
THE USE AND INFLUENCE OF SCIENTIFIC INFORMATION IN ENVIRONMENTAL POLICY MAKING: LESSONS LEARNED FROM NOVA SCOTIA
}

\author{
SUZUETTE S. SOOMAI* \\ Faculty of Graduate Studies, Dalhousie University, \\ Halifax, Nova Scotia
}

\begin{abstract}
Governmental organisations produce vast quantities of scientific information on the state of the marine and coastal environment which is often intended to guide policy-making to mitigate or reverse the declining trends in the health of the environment. How scientific information is used and how it influences environmental policy and decision making are however not well understood. The apparent disconnect between the knowledge and information produced by scientists and that used by policy makers is attributed to problems at the science-policy interface. Based on a multidisciplinary literature review, this paper describes how policy makers seek out and use scientific information within the context of policy design in the $21^{\text {st }}$ century. Best practices for increasing information flows across the science-policy interface are drawn from a study of the awareness, use, and influence of The 2009 State of the Nova Scotia Coast Report in coastal policy making in Nova Scotia.

Strategic or rational approaches to policy making can increase the twoway flow of information across the science-policy interface as it facilitates collaboration among multiple actors in information generation, transmission, and use. The production, use, and influence of The 2009 State of Nova Scotia's Coast Report in coastal policy making in Nova Scotia demonstrates the strategic approach to policy making whereby coastal policy is being developed through (i) intergovernmental partnerships, (ii) the use of best available information, (iii) linkages between the policy process and policy output, and (iv) public participation.
\end{abstract}

\section{INTRODUCTION}

Given the complex nature of modern environmental problems (e.g., the effects of climate change, overfishing, and pollution), it is essential that policy makers and their advisors receive relevant information

* Author to whom correspondence should be addressed: suzuette.soomai@dal.ca 
to develop policies to mitigate these environmental crises (Ascher, Steelman, \& Healy, 2010; Lubchenco, 1998). Making sound environmental policy decisions requires input from scientific information from various disciplines which is available from diverse sources (e.g., academic institutions, governmental agencies, and non-governmental organisations), in different genres (e.g., technical report and journal series), and in different formats (e.g., print and digital). While marine environmental policy and decision making are complex processes, they may be further complicated due to vast quantities of information available to policy makers and their advisors.

Modern policy making prescribes the use of the best available information for policy making (Bardach, 2004; Doern \& Phidd, 1992, Pal, 2010); however, the profile of scientific information in policy making typically remains low (Kahan, 2010: Likens, 2010). How scientific information is used and how it influences environmental policy and decision making are not well understood. Researchers sometimes attribute the apparent disconnect between the knowledge and information produced by scientists and that used by policy makers to problems at the "science-policy interface" (Ascher, Steelman, \& Healy, 2010; Doern \& Reed, 2000; Keller, 2009; Mitchell, 2010; Mitchell, Clark, \& Cash, 2006; Mol, 2008).

Given the modern policy making process and the magnitude of available information, what information do policy and decision makers need to make the right policy decisions on marine environmental issues? Drawing on a literature review in the fields of public policy, information management, and resource management, this paper describes how policy makers seek out and use scientific information in the context of policy design in the $21^{\text {st }}$ century. Some enablers and barriers to the flow of scientific information produced by governmental agencies within the science-policy interface will be highlighted. Best practices for increasing information flows across the interface are described based on a recent study of the awareness, use, and influence of environmental information in coastal policy making in Nova Scotia (Soomai, MacDonald, \& Wells, 2011). 


\section{PRODUCTION, USE, AND INFLUENCE OF SCIENTIFIC INFORMATION}

Global attention to marine environmental issues has increased substantially since the 1972 Stockholm Declaration on the Human Environment and the 1992 United Nations Conference on Environment and Development became platforms for modern environmental conservation and protection (United Nations, 1972; 1992). Vast quantities of technical publications have been produced by governmental and intergovernmental organizations in response to demands for solutions to marine environmental crises (e.g., MEA, 2005; Pew Environmental Group, 2011). Produced by governmental agencies, these publications are known as grey literature as they are not published by commercial publishers (GreyNet, 2012). Governmental agencies often see production of scientific information as one of their primary responsibilities in order to offer solutions to mitigate coastal and marine environmental problems and to inform policy decisions.

The use and influence of scientific information in environmental policy making is demonstrated in the routine workings of government. Policy analysts, through ongoing monitoring and assessment of available information, inform their ministers of emerging issues that can affect environmental policy agendas (Doern \& Phidd, 1992; Lindquist, 2001; Pal, 2010). Ministers bring policy issues and policy alternatives for action to Cabinet in memoranda that summarize environmental decisions and/or in more detailed discussion papers (Doern \& Phidd, 1992). In the last year of a government's term of office, detailed assessments of major trends and issues facing the country, key policy challenges and gaps, and proposed policy directions are often prepared as a "road map" for managing an overall policy agenda (Bardach, 2004; Doern \& Phidd, 1992; Lindquist, 2001; Pal, 2010). Access to the "right" information by policy and decision makers is undoubtedly a critical requirement for defining policy issues and for developing appropriate policy options.

In this paper, "use and influence" in policy contexts are viewed as a single concept and can be of a direct or an indirect nature. Scientific information can be used for direct problem-solving to address an environmental issue. More often, examples of indirect use are noted; for instance, the production of information can lead to a dynamic relationship between scientists, policy makers, and other actors in the policy process, or an increase in overall knowledge, understanding and 
attitudes of policy makers and practitioners on environmental issues. Further, use and influence of scientific information may depend on the intended purpose of scientific publications.

\section{POLICY DESIGN IN THE 21ST CENTURY}

Modern policy making is described as a strategic or rational approach with clearly defined linkages between stages in the policy process and policy outcome. The strategic approach seeks to identify a problem, to examine policy alternatives to solve the problem, to select the best policy alternative, to implement the decision, to evaluate the degree of success of the policy choice, and to modify the policy as needed (Bryson, Crosby, \& Stone, 2006; Howlett, Ramesh, \& Perl, 2009; Pal, 2010). Many countries are adopting evidence-based policy making as a common strategic approach to reform and restructure the policy process (Howlett, 2005; Nutley, Walter, \& Davies, 2007; Pawson, 2006). Evidence-based policy making aims to minimise policy failures by using the best available evidence from research to inform decisions about policies, programmes and projects. In the process, the experience, expertise, and judgment of policy and decision makers and scientists are integrated to formulate environmental policy alternatives (Brodhag \& Talière, 2006; Head, 2008). Strategic approaches are becoming necessary due to increasing public demand for accountability and governments' recognition that transparency in public policy leads to more effective governance (OECD, 2003). The strategic approach is also believed to be essential for addressing complex environmental problems (e.g., global climate change) which require coordination of local, national, and international efforts to maximise the effectiveness of limited resources devoted to environmental protection (Chasek, Downie, \& Brown, 2010; Pielke, 2007; Young, 2008).

Modern policy-making has extended beyond core government structures to include external interests and stakeholders. These wide policy communities or policy networks are characteristic of strategic governance and encourage government partnerships for joint research and the delivery of government services (Newman \& Tanguay, 2002; OECD, 2003; Pal, 2010). Policy communities include government agencies, pressure groups, media, academics, and individuals who have an interest in a particular policy area. Most governments now 
recognize the need to engage civil society through interest groups and social movements and to use a range of tools for public consultation and citizen engagement in policy making. It is believed that the more inclusive the interests and organizations in a sector are involved, the easier it is to implement policy decisions.

Despite advances in policy making in the $21^{\text {st }}$ century, elements of a less structured approach to policy making persist which can mask the existence of any overall strategic approach (Howlett, Ramesh, \& Perl, 2009; Pal, 2010). Traditional policy making has been described as an incremental approach or "muddling through," whereby new policies are formed through a series of incremental changes and differ in relatively small degrees to those already in place (Dror, 1969; Lindblom, 1959; Scott, 2010). Long-term policy considerations are generally omitted on the grounds of claims of limited data and information available to policy analysts to recommend policy alternatives. The validity of the incremental approach is debatable; however, it describes the risk adverse nature of policy makers who rely on the use of a series of small iterative policy changes instead of choosing a one-off policy approach (Doern, 1993; Doern \& Phidd, 1992; Doern \& Reed, 1992; Howlett, Ramesh, \& Perl, 2009; Hutchings, Walters, \& Haedrich, 1997; Lindquist, 2001; Scott, 2010).

\section{ENABLERS AND BARRIERS TO THE USE AND INFLUENCE OF SCIENTIFIC INFORMATION}

\section{How policy makers obtain and use information contained in scientific reports}

Policy makers and their advisors commonly seek information first from personal rather than from published sources (Clark \& Holmes, 2010; Holmes \& Savgård, 2008; Nutley, Walter, \& Davies, 2007). Personal sources include peers and scientists who may belong to boundary organizations. Boundary organisations integrate the domains of science and policy by translating scientific information for less technical audiences, and they often retain staff who actively broker links between policy advisers/policy makers and scientists (Thelwall, Klitkou, Verbeek, Stuart, \& Vincent, 2010;Young, 2008). Information seeking is also facilitated by scientists who are personally motivated to communicate with advisers and policy people. 
The main forms of written material used by policy makers and advisers are reviews and updates which summarize available scientific information (Clark \& Holmes, 2010; Hemsley-Brown, 2004; McNie, 2007). Policy makers prefer to use reports commissioned by government departments and agencies as they contain information that is more likely to be policy-relevant than is found in purely academic research publications. Policy makers and advisors want technical reports to contain short summaries written in less technical language, giving definitive conclusions, firm recommendations, and clear directions for action (Clark \& Holmes, 2010). If an author does not provide a summary, policy makers may rely on one prepared by an external body which may alter the original meaning of the information.

Policy makers seek out information on the impacts and causes of environmental issues in order to develop informed policy alternatives. While in some cases problems can be addressed at enormous costs, causes of problems are often beyond the control of policy interventions. For example, the prevalence of marine invasive species off mainland Nova Scotia and in the Bras d'Or Lakes (DFO, 2012) may be due in part to increases in international shipping activities; however, the policy answer may not lie in addressing shipping but by dealing with the consequences of the spread of the invasive species.

Using strategic approaches to policy making, policy makers seek to formulate equitable environmental policy options where effects (e.g., monetary benefits) or effort (e.g., monetary costs) are fairly or justly distributed (Howlett, Ramesh, \& Perl, 2009; Patton \& Sawicki, 1993). Information from various disciplines (e.g., social, environmental, and economics) is needed to make equitable policy decisions. However, policy makers may not be skilled in integrating knowledge from different scientific disciplines when developing environmental policy (Doern, 1993; Hutchings, 1997). Policy analysts (civil servants) then "translate" available scientific information into a form that can be used by policy makers (politicians) (Ouimet et al., 2010). Scientific reports are first rewritten to interpret technical details and scientific uncertainties; then the information from various disciplines are compared and filtered for use based on administrative and legal criteria (Asher, Steelman, \& Healey, 2010; Keller, 2009). Policy alternatives and preferences emerge out of this filtered information and the process may be as much political as it is technical. The challenge in communicating inherently interdisciplinary information is also 
noted when policy makers use ambiguous terminologies to describe environmental policy decisions in legislation.

\section{How government organisational structure and culture influ- ence information use}

The traditional hierarchical structure of government bureaucracy creates departmentalisation and centralisation which can limit communication of information and potentially cause conflict within the public service (Doern, 1993; Yang \& Maxwell, 2011). In departmentalization, multiple departments share responsibility for aspects of environmental policy, each with a different functional mandate. In centralization, power and authority are located at higher management levels, i.e., the "top-down" approach. Each level of government (e.g., federal, provincial, and municipal) may have different interests or value systems (e.g., economic, social, and biological) by which they weigh the importance of environmental management and information use. For example, in Canada federal departments are the front players in policy development and the inter-departmental politics involved in environmental policy making (Doern, 1993; Howlett, Ramesh, \& Perl, 2009). Jurisdictional concerns arise where ministers and senior public servants debate whether selected environmental initiatives will adversely affect or unintentionally change policy in their sphere of responsibility (Howlett \& Wellstead, 2011). How information is used in different jurisdictions will vary and the process becomes more complicated when individuals operate within intra- and interorganization arrangements.

With the increasing move toward strategic approaches to policy making, more governmental agencies now operate within complex policy making networks, which consist of formal or informal links within and across government departments and external agencies (Lindquist, 2001; Newman \& Tanquay, 2002; Pross, 1992; OECD, 2003, 2001). These networks reflect wide policy communities and are comprised of a range of actors including industry, scientists, government, and interest groups. The various actors each play a unique role in information production, dissemination, and use within the policy making community.

Policy analysts now have access to information and tools to facilitate a thorough understanding of existing problems and likely impacts of policy as well as a requirement to consult with wide audiences (Scott, 2010). The tools include sophisticated databases for storage, retrieval, 
and analysis of relevant data; modeling and forecasting tools; information communication technologies; and social networks. The databases and information technologies themselves present limitations as they are often too technical for policy makers to take advantage of personally. Staff with expertise in using these new data and communication technologies can be employed within government agencies to assist in translation of technical information for use by policy makers.

\section{LESSONS LEARNED FROM COASTAL POLICY MAKING IN NOVA SCOTIA}

Recent coastal policy making in Nova Scotia illustrates the production, use, and influence of environmental information within a strategic policy design context. In 2009, the Government of Nova Scotia published The 2009 State of Nova Scotia's Coast Report in three forms - a detailed technical report, a 26-page summary document, and six four-page fact sheets (Government of Nova Scotia, 2009). The Report consolidates current scientific knowledge on the province's coastal areas and focuses on six priority issues: sea-level rise and storm events, public coastal access, working waterfronts, coastal water quality, coastal ecosystems and habitats, and coastal development. The Report was designed to reach and inform Nova Scotians about coastal issues and to encourage public participation in the development of coastal policy in Nova Scotia. The three components of the Report were published in print and Web-based formats, and the fact sheets and summary document were produced in English and French editions. Since its release, the Government of Nova Scotia took steps to raise public awareness of the Report so as to increase public participation in the review and completion of a coastal policy, the Coastal Strategy, a draft of which was released in October 2011 (Government of Nova Scotia, 2011a). A case study of the awareness, use, and influence of The 2009 State of Nova Scotia's Coast Report from the date of the release of the Report was conducted in collaboration with the provincial government (Soomai, MacDonald, \& Wells, 2011).

The production, use, and influence of scientific information in coastal policy making in Nova Scotia demonstrates the strategic approach to policy making whereby coastal policy is being developed through (i) intergovernmental partnerships, (ii) use of best available 
information, (iii) linkages between the policy process and policy output, and (iv) public participation.

The Provincial Oceans Network, composed of representatives from 15 provincial departments and agencies with responsibilities and interests in coastal and ocean management, facilitated the government's new approach to coastal management (Government of Nova Scotia, 2007). Production of The 2009 State of Nova Scotia's Coast Report was the responsibility of representatives of the Network, i.e., experts from each provincial government department. The six priority issues were common matters facing each of the 15 departments and needed to be addressed collectively. The issues also reflected the views of community groups and the general public which had directed concerns to the relevant line agencies over several decades.

After the launch of The 2009 State of Nova Scotia's Coast Report, the Provincial Oceans Network conducted public consultation to promote awareness and use of the Report and to obtain feedback from the public about which of the six issues should be considered to be priority. This feedback was used to guide the development of the Coastal Strategy. Public consultation included open houses throughout the province and a multi-stakeholder meeting. In addition, a provincewide telephone survey was conducted, and the public could submit comments via the government's Web site. Subsequently, the province released a "What we Heard" report, which provided feedback on its public consultations (Government of Nova Scotia, 2011b).

The production of scientific information used in the coastal policy process was linked to the policy output. The 2009 State of Nova Scotia's Coast Report (Government of Nova Scotia, 2009), was seen to be both an input and an output of policy and decision making (Soomai, MacDonald, \& Wells, 2011). The intended policy endpoint, the Coastal Strategy, was the driving factor in the production of The 2009 State of Nova Scotia's Coast Report. In turn, feedback from the public consultation on the Report was used to produce the draft Coastal Strategy.

Communication of The 2009 State of Nova Scotia's Coast Report in less technical formats facilitated the flow of information across the science-policy divide. The various components of the Report enabled use by multiple audiences (Soomai, MacDonald, \& Wells, 2011). Email social networks played a key role in promoting awareness of the Report among established groups which traditionally 
respond to government surveys and interviews (Soomai, MacDonald, \&Wells, 2011).

Many government organizations have not undertaken an analysis of the use and influence of their publications and these processes are still poorly understood. However, in the case of The 2009 State of Nova Scotia's Coast Report, the Government of Nova Scotia initiated the case study on awareness, use, and influence of the Report, signifying government's recognition of the importance of information in policy making (Soomai, MacDonald, \& Wells, 2011).

\section{DISCUSSION}

The policy process filters scientific information (based on systematic analysis of trends and causal relationships by scientists in various disciplines) and political knowledge of policy makers (based on their expertise in contextual judgement and persuasion) to create new integrated knowledge. This new knowledge represents the merging of science and policy and guides the production of policy options. The increasing number of actors involved in wide policy communities can ensure that diverse sources of information (various scientific disciplines and local knowledge) are included in the filtering process. Effective flow of information across the science-policy interface depends on how well scientific and political knowledge is filtered during the policy process and how well it is utilised or interpreted in the environmental policy output.

Scientists and policy makers need to understand the strengths and weaknesses of the filters that come into play when knowledge (scientific and political) enters the policy process. Scientists need to understand the policy making process and this understanding should feed back into production of clearly presented and readily accessible information suitable for the policy process. Policy makers need to maintain diverse channels of information sources and be open to different perspectives from the various scientific disciplines. Policy makers may not be comfortable using and interpreting science and need a core group of technical support staff who can liaise with scientists. Policy makers face challenges in extracting "useful" information from scientific uncertainty and in integrating necessary information from diverse sources and multiple disciplines into policy alternatives. 
The importance of boundary organisations engaged in translation of technical information for less technical audiences is apparent here.

Scientific information that enters the policy process must have the characteristics of salience, reliability and credibility (Delaney \& Hastie, 2007; Holmes \& Savgard, 2008; MacDonald et al., 2010; Mitchell et al., 2006). Scientists who integrate priority societal needs into their research will improve the likelihood that the research results will be useful for making policy as policy-makers respond more readily to research that affects their constituents' or clients' needs. Scientists can also consider conducting scientific research that acknowledges government's constraints in policy making and policy implementation. Selecting research questions relevant to the most pressing policy issues helps build interest and support for scientific research. Scientists can also seek input on the selection of priority research questions from policy makers. Co-production of information involving scientists and policy makers can ensure that research agendas are relevant to policy agendas as seen in the case of The 2009 State of Nova Scotia's Coast Report. Co-production of information can also make scientific uncertainties more visible to policy makers and scientists can answer specific questions that are important to policymakers.

Many government policies have been designed to increase economic growth and improve social benefits while policies for environmental management and sustainable development are a relatively new phenomenon. Policy makers still appear to be uncertain as to how completely new marine environmental policies will fare since there are few similar policies for comparison. Both incremental and strategic approaches to policy design are at work and must be kept in a balance. The risk adverse nature of policy makers in the environmental policy process is characteristic of the incremental approach and appears to maintain a disconnect at science-policy divide. Belief in the incremental approach may inherently jeopardize the progress of government policy making in the $21^{\text {st }}$ century by promoting the now "dated" concept of insufficient information on which to base environmental policy. Weiss (1982) stated that any attempt to increase the availability of information to policy makers will increase the evidence used in decision making. Strategic approaches to policy making creates an appropriate institutional framework linking policy makers, researchers, and other stakeholders. 


\section{CONCLUSIONS}

Scientists and policy makers play unique roles in facilitating the flow of information across the science-policy interface. Effective communication between scientists and policy makers, formal institutional relationships, trust, and mutual respect are critical factors in facilitating information use in policy making. Policy problems can be clearly defined if the information that policy makers receive is clearly written, with understandable technical details, and available in a summary.

Strategic approaches to policy making can increase the two-way flow of information across the science-policy interface as it facilitates collaboration among multiple actors in information generation, transmission, and use. Through strategic approaches to policy making, governments can increase their institutional capacities to share information among their agencies, anticipate scientific uncertainty, increase trust and sharing of values through dialogue and commitment building, and implement alternative delivery systems to meet policy objectives. The development of strategic plans with a clear organizational vision, mandate, strategic goals, and expected outputs provides the groundwork for increasing information use in policy development.

Recognition of the importance of using scientific information in policy making is characteristic of the strategic approach to policy making which was clearly demonstrated in recent coastal policy making in Nova Scotia. Best practices for increasing scientific information flows across the science-policy interface include: (1) use of several communication methods to reach diverse audiences; (2) production of scientific information through intergovernmental partnerships to provide current and reliable information for policy making; (3) clear linkages between the information used in the policy process and policy output; and (4) public participation in policy making. The attention given to the production of less technical versions of The 2009 State of Nova Scotia's Coast Report (fact sheets and summary documents) is consistent with recommendations in the scholarly literature on communication of scientific information (e.g. Clark \& Holmes, 2010; McNie, 2007). 


\section{REFERENCES}

Ascher,W.,Steelman, T., \& Healy, R.(2010). Knowledge and environmental policy: Reimagining the boundaries of science and politics. Cambridge, MA: MIT Press.

Bardach, E. (2004). A practical guide for policy analysis: The eightfold path to more effective problem solving. Washington: CQ Press.

Brodhag, C., \& Talière, S. (2006). Sustainable development strategies: Tools for policy coherence. Natural Resources Forum, 30(2): 136-145.

Bryson, J. M., Crosby, B. C., \& Stone, M. M. (2006). The design and implementation of cross-sector collaborations: Propositions from the literature. Public Administration Review, 66, 44.

Chasek, P., Downie, D., \& Brown, J. W. (2010). Global environmental politics. Boulder, CO: Westview Press.

Clark, R., \& Holmes, J. (2010). Improving input from research to environmental policy: Challenges of structure and culture. Science and Public Policy, 37(10): 751-764.

Delaney, A., \& Hastie, J. (2007). Lost in translation: Differences in role identities between fisheries scientists and managers. Ocean \& Coastal Management, 50: 661-682.

Department of Fisheries and Oceans (DFO). (2012). First Nations, DFO collaborate on Bras d'Or Lakes research. Retrieved from http://www. dfo-mpo.gc.ca/science/Publications/article/2007/13-07-2007-eng.htm

Doern, G. B. (1993). Green diplomacy: How environmental policy decisions are made. Toronto: $\mathrm{C}, \mathrm{D}$. Howe Institute.

Doern, G. B., \& Phidd, R. W. (1992). Canadian public policy: Ideas, structure, process. Scarborough, Canada: Nelson.

Doern, G.B., \& Reed,E. (2000). Risky business - Canada's changing sciencebased policy \& regulatory regime. Toronto: University of Toronto Press.

Dror, Y. (1969). The prediction of political feasibility. Futures, 1(4): 282288. Retrieved from http://www.rand.org/pubs/papers/2008/P4044.pdf.

Government of Nova Scotia. (2007). Provincial Oceans Network (PON). Retrieved from http://www.gov.ns.ca/fish/marine/coastalzone/pon.shtml

Government of Nova Scotia. (2009). The 2009 state of Nova Scotia's coast technical report. Retrieved from http://www.gov.ns.ca/coast

Government of Nova Scotia.(2011a). Draft coastal strategy. Retrieved from http://www.gov.ns.ca/coast/documents/draft-coastal-strategy201loct.pdf

Government of Nova Scotia. (2011b). What we heard. Nova Scotia's 2010 coastal consultation. Retrieved from http://www.gov.ns.ca/ coast/2010consultationreport.asp.

GreyNet. (2012). Grey literature. GreyNet- Grey literature network service. Retrieved from http://www.greynet.org/greynethome/aboutgreynet.html

Head, B.W. (2008). Three lenses of evidence-based policy. Australian Journal of Public Administration, 67(1): 1-11.

Hemsley-Brown, J. (2004). Facilitating research utilisation: A cross-sector review of research evidence. The International Journal of Public Sector Management, 17(6): 534-552. 
Holmes J., \& Savgård, J. (2008). Dissemination and implementation of environmental research - including guidelines for best practice. Swedish Environmental Protection Agency Report, 5681.

Howlett, M. (2005). Policy analytical capacity and evidence-based policymaking: Lessons from Canada. Canadian Public Administration, 52(2): 153-175.

Howlett, M., Ramesh, M., \& Perl, A. (2009). Studying public policy: Policy cycles \& policy subsystems. Toronto: Oxford University Press.

Howlett, M. \& Wellstead, A. (2011). Policy analysts in the bureaucracy revisited: The nature of professional policy work in contemporary government. Politics \& Policy, 49(4): 613-633.

Hutchings, J. A., Walters, C., \& Haedrich, R. L. (1997). Is scientific inquiry incompatible with government information control? Canadian Journal of Fisheries and Aquatic Sciences, 54: 1198-1210.

Kahan, D. (2010). Fixing the communications failure. Nature, 463 (7279): 296-297.

Keller, A. (2009). Science in environmental policy: The politics of objective advice. Cambridge, MA: MIT Press.

Likens, G.E.(2010). The role of science in decision making: Does evidencebased science drive environmental policy? Frontiers of Ecology and the Environment, 8: 1-9.

Lindblom, C. E. (1959). The science of "muddling" through. Public Administration Review, 19(2): 79-88.

Lindquist, E. A. (2001). How Ottawa plans: The evolution of strategic planning. In L. A. Pal (Ed.), How Ottawa spends, 2001-2002 power in transition (pp. 61-93). Toronto: Oxford University Press.

Lubchenco, J. (1998). Entering the century of the environment: A new social contract for science. Science 23 (5350): 279.

MacDonald, B. H., Wells, P. G., Cordes, R. E., Hutton, G. R. G., Cossarini, D. M., \& Soomai, S. S. (2010). The use and influence of information produced as grey literature by international, intergovernmental marine organizations: Overview of current research. In D. J. Farace, \& J. Schöpfel. (Eds.), Grey literature in library and information studies (pp. 67-180). Berlin: De Gruyter Saur.

McNie, E. C. (2007). Reconciling the supply of scientific information with user demands: An analysis of the problem and review of the literature. Environmental Science \& Policy, 10: 17-38.

Millennium Ecosystem Assessment (MEA). (2005). Millennium ecosystem assessment synthesis Report. Retrieved from http:/www.milleniumassessment.org/en/index/aspx.

Mitchell, R.B. (2010). International politics and the environment. London: SAGE Publishing Ltd.

Mitchell, R. B., Clark, W. C., Cash, D. W., \& Dickson, N. M. (2006). Information and influence. In R. B. Mitchell, W. C. Clark, D. W. Cash, \& N. M. Dickson, (Eds.), Global environmental assessments: Information and influence, (pp. 307-338). Cambridge, MA: MIT Press. 
Mol. A. P. J. (2008). Environmental reform in the information age. The contours of informational governance. New York: Cambridge University Press.

Newman, J., \& Tanguay, A. B. (2002). Crashing the party: The politics of interest groups and social movements. In J. Everitt \& B. O'Neill. (Eds.), Citizen politics: Research and theory in Canadian political behaviour, (pp. 387-412). Toronto: Oxford.

Nutley, S., Walter, I., \& Davies, H. T. O. (2007). Using evidence: How research can inform public services. University of Bristol: The Policy Press.

OECD. (2003). Policy coherence: Vital for global development. OECD Policy brief.Retrieved from http://www.oecd.org/dataoecd/11/35/20202515.pdf.

OECD. (2001). Engaging citizens in policy-making: Information, consultation and public consultation. PUMA Policy Brief, 10. France: OECD.

Ouimet, M., Bédard, P., Turgeon, J., Lavis, J. N., Gélineau, F., Gagnon, F., \& Dallaire, C. (2010). Correlates of consulting research evidence among policy analysts in government ministries: A cross-sectional survey. Evidence \& Policy, 6(4): 433-460.

Pal, L. A. (2010). Beyond policy analysis: Public issue management in turbulent times. Toronto: Nelson Education.

Patton, C. V., \& Sawicki, D. S. (1993). Basic methods in policy analysis and planning. Englewood Cliffs: Prentice Hall.

Pawson, R. (2006). Evidence-based policy: A realist perspective. London: Sage Publications.

Pielke, R. A. (2007). The honest broker. Making sense of science in policy and politics. Cambridge: Cambridge University Press.

Pross, P. (1992). Group politics and public policy. Canada: Oxford University Press.

Pew Environmental Group.(2011). Ocean earth: How Rio +20 can and must turn the tide. Retrieved from http:/www.pewenvironment.org/uploadedFiles/PEG/Publications/Report/Pew-OceanEarth-PolicyStatement.pdf.

Scott, R. (2010). The science of muddling through revisited. Emergence: Complexity and Organization, 12(1): 5-18.

Soomai, S. S., MacDonald, B. H., \& Wells, P. G. (2011). The 2009 state of Nova Scotia's coast report: An initial study of its use and influence. Halifax: Dalhousie University. Retrieved from http://www.eiui.ca/sites/ default/files/StateOfTheGulfOfMaineReport_AnInitialStudyOnAwarenessUseAndInfluence.pdf

Thelwall, M., Klitkou, A., Verbeek, A., Stuart, D., \& Vincent, C. (2010). Policy-relevant webometrics for individual scientific fields. Journal of the American Society for Information Science and Technology, 61: 1464-1475.

United Nations. (1972). Declaration of the United Nations Conference on the Human Environment, Stockholm, 16 June 1972, UN Doc. A/ CONF.48/14/Rev.1.

United Nations. (1992). Agenda 21. In Report of the United Nations Conference on Environment and Development, Rio de Janeiro, UN Doc. A/ CONF.151/26/Rev.1 (Vol. 1), Annex II. 
Weiss, J. A. (1982). Coping with complexity: An experimental study of public policy decision-making. Journal of Policy Analysis and Management, 2(1): 66-87.

Yang, T., \& Maxwell, T. A. (2011). Information-sharing in public organizations: A literature review of interpersonal, intra-organizational and inter-organizational success factors. Government Information Quarterly, 28(2): 164-175.

Young, O.R. (2008). Institutions and environmental change. The scientific legacy of a decade of IDGEC research. In O. R. Young, L. A. King, \& H. Schroeder (Eds.), Institutions and environmental change: Principal findings, applications, and research (pp. 3-46). Cambridge MA: MIT Press. 